\title{
Kontribusi Gaya Kepemimpinan Situasional Kepala Sekolah dan Resiliensi Diri Guru Terhadap Kinerja Guru
}

\section{Kadek Jaya Sentana ${ }^{1 *}$, I Komang Ngurah Wiyasa ${ }^{2}$}

${ }^{12}$ Program Studi Guru Sekolah Dasar, Universitas Pendidikan Ganesha, Singaraja, Indonesia

\section{A R T I C LE INFO Article history: \\ Received 1 Januari 2021 Received in revised form 30 Januari 2021 Accepted 1 Maret 2021 Available online 8 April 2021}

\section{Kata Kunci:} kepemimpinan, kepala sekolah, kinerja guru

Keywords: leadership, principal, teacher performance

\begin{abstract}
A B S T R A K
Kinerja guru yang belum optimal disebabkan oleh gaya kepemimpinan kepala sekolah yang tidak sesuai dengan yang diharapkan dan kurang optimalnya resiliensi diri guru terhadap kinerja guru. Penelitian ini bertujuan menganalisis kontribusi gaya kepemimpinan situasional kepala sekolah dan resiliensi diri guru terhadap kinerja guru. Penelitian ini termasuk ke dalam jenis penelitian studi korelasi (expost facto). Populasi dalam penelitian ini berjumlah 35 dan dibatasi untuk guru yang PNS. Sampel ditentukan dengan tehnik sampling total. Pengumpulan data dengan pengisian angket. Uji hipotesis dilakukan dengan teknik analisis regresi linier sederhana dan teknik analisis regresi linier ganda setelah semua uji prasyarat terpenuhi. Hasil penelitian ini menunjukkan bahwa gaya kepemimpinan situasional kepala sekolah terhadap kinerja guru sebesar $11,24 \%$, resiliensi diri guru terhadap kinerja guru sebesar $51,04 \%$, dan gaya kepemimpinan situasional kepala sekolah dan resiliensi diri guru terhadap kinerja guru sebesar $62.28 \%$. Simpulan penelitian ini adalah gaya kepemimpinan situasional dan resiliensi diri guru memiliki kontribusi terhadap kinerja guru. Implikasi penelitian ini adalah meningkatkan mutu
\end{abstract} sekolah, dan dijadikan sebagai pedoman untuk meningkatkan kualitas guru dan seluruh staf sekolah.

\begin{abstract}
A B S T R A C T
Teacher performance is not optimal due to the principal's leadership style that is not as expected and less than optimal teacher self-resilience to teacher performance. This study aims to analyze the contribution of the principal's situational leadership style and teacher self-resilience to teacher performance. This research belongs to the type of correlation study research (ex post facto). The population in this study amounted to 35 and was limited to teachers who were civil servants. The sample is determined by total sampling technique. Data collection by filling out a questionnaire. Hypothesis testing is performed using simple linear regression analysis techniques and multiple linear regression analysis techniques after all the prerequisite tests are met. The results of this study indicate that the principal's situational leadership style on teacher performance is $11.24 \%$, the teacher's self-resilience to teacher performance is $51.04 \%$, and the principal's situational leadership style and teachers' self-resilience to teacher performance is $62.28 \%$. The conclusion of this study is that the situational leadership style and teacher self-resilience have contributed to teacher performance. The implication of this research is to improve the quality of schools, and serve as guidelines for improving the quality of teachers and all school staff.
\end{abstract}

\section{Pendahuluan}

Pada saat ini Indonesia mengalami rendahnya mutu pendidikan yang terjadi di setiap jenjang pendidikan. Harus diakui bahwa peran dan fungsi guru dalam proses pembelajaran masih mendominasi dan memiliki peran yang strategis, sehingga keberhasilan tujuan pendidikan sangat bergantung pada kontribusi kinerja guru. Hal ini kelak akan berakibat adanya perbedaan kinerja guru dalam meningkatkan mutu pendidikan. Kualitas dari kinerja guru menempati posisi strategis yang penting,, karena guru merupakan garda depan dari seluruh proses pendidikan sekolah (Ahmadiansah, 2016; Dwiyani \& Sarino, 2018; Priyono et al., 2018). 
Kinerja guru adalah suatu upaya dari guru untuk mencapai tujuan pendidikan yang diharapkan oleh sekolah berupa kualitas dan kuantitas hasil pekerjaan seperti: tidak terlambat dalam penyelesaian pekerjaan, prakarsa dalam menyelesaikan pekerjaan guru, dan kepala sekolah sebagai pembimbing langsung akan mengevaluasi guru sesuai dengan pekerjaan yang disepakati bersama (Ardiana, 2017; Hafid, 2017; Nugraha, 2017). Kinerja guru dapat diartikan sebagai hasil yang diperoleh ketika guru melaksanakan tugas (mengajar) sesuai standar kinerja yang ditetapkan oleh sekolah, seperti merencanakan rencana pembelajaran, melaksanakan kegiatan pembelajaran dan mengevaluasi hasil belajar. Kinerja seorang guru dikatakan baik jika guru mampu menguasai dan mengembangkan materi pembelajaran, belajar kreatif, menunjukkan komitmen yang tinggi terhadap tugas mengajar, disiplin kerja, bekerjasama dengan seluruh warga sekolah dan berkepribadian, maka dikatakan guru berprestasi dengan baik dianggap panutan bagi siswa (Dudung, 2018; Salmawati et al., 2017; Suyitno, 2018).

Guru dapat dikatakan sebagai profesi yang mulia, dan masyarakat Indonesia sering menyebut guru sebagai pahlawan tanpa tanda jasa. Istilah tersebut digunakan karena guru dianggap sebagai profesi yang tidak memerlukan imbalan atas jasanya. Guru merupakan faktor yang paling berpengaruh dalam proses dan terciptanya pendidikan yang bermutu tinggi (Kartowagiran, 2015; Pramesti \& Muhyadi, 2018; Susanti, 2016). Namun kinerja guru dapat terganggu jika kepemimpinan kepala sekolah kurang memuaskan dan ditambah resiliensi guru yang belum optimal.

Berdasarkan hasil observasi di SD Gugus 1 Kecamatan Blahbatuh Tahun Ajaran 2020/2021 permasalahan yang terjadi saat ini yaitu, masih kurangnya kinerja guru dalam suatu sekolah dikarenakan gaya kepemimpinan kepala sekolah tidak sesuai dengan yang diharapkan anggotanya dan kurang optimalnya resiliensi diri guru sehingga menyebabkan tidak baiknya pengendalian diri dari guru. Selain itu, hampir di setiap sekolah seperti guru masih ada yang belum membuat persiapan pembelajaran sebelum mengajar, guru yang belum dapat mengkondusifkan keadaan kelas menjadi tenang ketika ada siswa yang melakukan keributan di kelas, guru dalam pelaksanaan pembelajaran juga belum menggunakan strategi pembelajaran yang bervariasi sehingga yang terjadi pembelajaran terasa membosankan bagi siswa, belum lagi kasus guru yang tertidur di kelas saat proses belajar mengajar berlangsung semua masalah tersebut terjadi karena turunnya kinerja dalam diri guru.

Berhasil tidaknya pendidikan dan pembelajaran sekolah juga dipengaruhi oleh kemampuan kepala sekolah dalam mengelola berbagai komponen sekolah. Kepala sekolah adalah seorang guru yang memiliki kemampuan untuk memimpin semua sumber daya sekolah guna mencapai tujuan bersama sebesar-besarnya (Luddin, 2014; Purwanti et al., 2014; Ramadoni et al., 2016). Kepemimpinan dapat diartikan sebagai kemampuan untuk mempengaruhi atau mendorong seseorang atau sekelompok orang untuk bekerja secara sukarela dalam situasi tertentu untuk mencapai tujuan tertentu.

Kepemimpinan dikatakan sebagai proses yang dilakukan pemimpin agar bisa dalam melakukan sesuatu dan kepemimpinan tidak hanya untuk menempati posisi otoritatif. Gaya kepemimpinan kepala sekolah merupakan salah satu yang dapat memajukan tujuan tertentu yang direncanakan. Kepemimpinan kepala sekolah yang baik dapat membuat anggotanya percaya, setia dan termotivasi untuk melaksanakan tugas organisasi secara maksimal (Sukiyanto \& Maulidah, 2020; Wahyudin, 2018; Yayuk \& Sugiyono, 2019). Di sekolah, gaya kepemimpinan situasional kepala sekolah sangat penting untuk mengatasi berbagai permasalahan di sekolah dan pendidikan guru.

Gaya kepemimpinan situasional merupakan model gaya kepemimpinan yang berfokus pada pengikut, pengikut yang relevan adalah karyawan di perusahaan (Saragih \& Simarmata, 2018; Umi et al., 2019; Yayuk \& Sugiyono, 2019). Kepemimpinan yang sukses dicapai dengan memilih cara memimpin yang benar, dan bergantung pada kesiapan dan kematangan pengikutnya. Gaya kepemimpinan situasional kepala sekolah yang efektif dapat diartikan sebagai pemimpin bisa meningkatkan kinerja semua anggotanya dalam mencapai tujuan tertentu. Menerapkan gaya kepemimpinan situasional dengan melihat kematangan dan kesiapan karyawan dan pendekatan gaya kepemimpinan situasional berfokus pada karyawan atau pengikut dalam organisasi.

Fungsi kepala sekolah sebagai pemimpin sekolah, yaitu: (1) meningkatkan mutu sekolah, seperti menyediakan fasilitas yang memadai bagi seluruh komponen sekolah; (2) Sebagai pedoman untuk meningkatkan kualitas guru dan seluruh staf sekolah melalui pertemuan, dan observasi kelas, (Aisyah \& Takdir, 2017; Dwiyani \& Sarino, 2018; Suparno, 2013). Fungsi tersebut dijadikan landasan untuk melaksanakan tugas kepala sekolah sebagai pemimpin sekolah misalnya mengajar guru, 
membimbing staf, membimbing siswa, melatih staf, mengikuti perkembangan iptek, dan sebagainya. Namun sebagai kepala sekolah yang baik harus menyadari pentingnya kinerja guru.

Secara teori terdapat banyak faktor yang dapat mempengaruhi kinerja guru, salah satunya adalah kemampuan manajemen kepala sekolah. Kepala sekolah berperan penting dalam pengelolaan lembaga sekolah, salah satunya meliputi aspek keuangan. Keuangan dan keuangan merupakan bagian integral dari manajemen pendidikan, dengan kata lain mengingat setiap kegiatan sekolah membutuhkan uang, maka diperlukan pengelolaan komponen keuangan dan keuangan ini secara lebih efektif, efektif, transparan dan bertanggung jawab agar dana yang ada dapat mendukung sekolah untuk mencapai tujuan pendidikan yang ada (Erawan \& Sukartha, 2018; Sukiyanto \& Maulidah, 2020; Winarsih, 2018). Keberhasilan penyelenggaraan pendidikan sebagai tolak ukur kinerja guru di sekolah bergantung pada kemampuan kepemimpinan kepala sekolah dalam mengelola staf sekolah. Faktor kepemimpinan utama dianggap memiliki peran penting, karena sebagai pemimpin sekolah maka gaya dan kebijakan kepemimpinan akan sangat mempengaruhi kinerja guru. Pendidikan di SD merupakan pondasi untuk mencapai tingkat pendidikan selanjutnya seperti SMP, SMA dan SMK maupun perguruan tinggi. Belum lagi guru terbebani oleh kompetensi yang distandarkan oleh pihak sekolah masing-masing. Kemampuan guru untuk bertahan dari tuntutan tersebut dapat dikatakan sebagai resiliensi.

Resiliensi adalah kekuatan yang dimiliki seseorang untuk menghadapi, mengatasi, dan untuk menjadi kuat terhadap kesulitan hidup yang tak dapat dihindari (Akbar \& Pratasiwi, 2017; Hafiva et al., 2020; Sutrisno, 2017). Selain itu resiliensi dapat diartikan sebagai ilmu psikologi positif yang menginstruksikan individu untuk lebih realistis dalam menghadapi masalah dalam hidup. Jika resiliensi guru terganggu makan akan berpengaruh juga dengan kinerja seorang guru.

Penelitian ini diperkuat dengan beberapa penelitian sebelumnya yang relevan dengan penelitian ini, seperti: (1) penelitian yang dilakukan oleh (Sukiyanto \& Maulidah, 2020), yang memperoleh hasil penelitian bahwa gaya kepemimpinan kepala sekolah dan budaya organisasi berpengaruh terhadap motivasi guru dan karyawan; (2) penelitian yang dilakukan oleh (Ramadoni et al., 2016), yang memperoleh hasil penelitian bahwa kepemimpinan kepala sekolah terbukti dapat meningkatkan kinerja guru; (3) penelitian yang dilakukan oleh (Umi et al., 2019), yang memperoleh hasil penelitian bahwa kepemimpinan kepala taman kanak-kanak berkorelasi terhadap kinerja kompetensi pedagogik dan kompetensi profesional guru.

Tujuan dari penelitian ini adalah untuk menganalisis besarnya kontribusi gaya kepemimpinan situasional kepala sekolah dan resiliensi diri guru terhadap kinerja guru SD gugus 1 kecamatan blahbatuh tahun ajaran 2020/2021.

\section{Metode}

Penelitian ini termasuk ke dalam jenis penelitian studi korelasi (expost facto). Penelitian ini dilaksanakan di SD Gugus 1 Kecamatan Blahbatuh, adapun dilaksanakannya penelitian ini untuk menganalisis besarnya kontribusi gaya kepemimpinan situasional kepala sekolah dan resiliensi diri guru terhadap kinerja guru.

Penelitian ini memuat dua variabel bebas dan satu variabel terikat, yaitu gaya kepemimpinan situasional kepala sekolah (X1) sebagai variabel bebas pertama, resiliensi diri guru (X2) sebagai variabel bebas ke dua dan kinerja guru SD (Y) sebagai variabel terikat. Populasi dalam penelitian ini berjumlah 35 dan dibatasi untuk kepala sekolah dan guru yang PNS di SD di Gugus I Blahbatuh. Sampel ditentukan dengan tehnik sampling total. Sampling total adalah penelitian yang dimana menggunakan seluruh populasi untuk diteliti. Jika penelitian yang dilakukan populasinya kurang dari 100 makan sebaiknya menggunakan sampling total, sehingga seluruh populasi dijadikan subjek yang akan dipelajari dan sebagai pemberi informasi. Dengan demikian seluruh guru yang telah berstatus PNS di SD Gugus I Blahbatuh dijadikan sampel dalam penelitian ini yang berjumlah 35 orang.

Data penelitian gaya kepemimpinan situasional kepala sekolah (X1), resiliensi diri guru (X2) dan kinerja guru $(\mathrm{Y})$ diperoleh melalui metode non tes dengan menyebarkan kuesioner. Kuesioner yang digunakan bersifat tertutup, memberikan pernyataan dan alternatif jawaban terkait variabel yang akan diukur, dan responden dapat memilih jawabannya. Alternatif jawaban kuesioner ini adalah skala likert, dengan rentang skor 1-4. Adapun kisi-kisi instrumen yang digunakan dapat dilihat pada Tabel 1, Tabel 2, dan Tabel 3. 
Tabel 1. Kisi-Kisi Instrumen Kinerja Guru

\begin{tabular}{|c|c|c|c|c|}
\hline Dimensi & Indikator & Positif(-) & Negati(+) & Jumlah \\
\hline \multirow[t]{7}{*}{ Pedagogik } & 1. Mengenal karakter peserta didik & 1 & 2 & 2 \\
\hline & $\begin{array}{l}\text { 2. Menguasai teori belajar dan prinsip- } \\
\text { prinsip pembelajaran yang mendidik }\end{array}$ & 3,30 & 4 & 3 \\
\hline & 3. Pengembangan kurikulum & 6 & 5 & 2 \\
\hline & 4. Kegiatan Pembelajaran yang mendidik & 8 & 7 & 2 \\
\hline & $\begin{array}{l}\text { 5. Memahami dan mengembangkan } \\
\text { potensi }\end{array}$ & 10 & 9 & 2 \\
\hline & 6. Komunikasi dengan peserta didik & 12 & 13 & 2 \\
\hline & 7. Penilaian dan evaluasi & 15 & 14 & 2 \\
\hline \multirow[t]{3}{*}{ Kepribadian } & $\begin{array}{l}\text { 8. Bertindak sesuai dengan norma agama, } \\
\text { hukum, sosial dan kebudayaan } \\
\text { Indonesia }\end{array}$ & 17 & 21 & 2 \\
\hline & $\begin{array}{l}\text { 9. Menunjukan pribadi yang dewasa dan } \\
\text { teladan }\end{array}$ & 20 & 16,31 & 3 \\
\hline & $\begin{array}{l}\text { 10. Memiliki tanggung jawab yang tinggi } \\
\text { dan rasa bangga menjadi guru }\end{array}$ & 23 & 22,35 & 3 \\
\hline \multirow[t]{2}{*}{ Sosial } & $\begin{array}{l}\text { 11. Bersikap inklusif, bertindak objektif, } \\
\text { serta tidak diskriminatif }\end{array}$ & 25 & 24,31 & 3 \\
\hline & $\begin{array}{l}\text { 12. Komunikasi dengan sesama guru, } \\
\text { tenaga Pendidikan, orang tua peserta } \\
\text { didik, dan masyarakat }\end{array}$ & 18,33 & 19 & 3 \\
\hline Profesional & $\begin{array}{l}\text { 13. Penguasaan materi struktur konsep dan } \\
\text { pola pikir keilmuan yang mendukung } \\
\text { mata pelajaran yang diampu } \\
\text { 14. Mengembangkan keprofesian melalui } \\
\text { tindakan reflektif }\end{array}$ & & & \\
\hline
\end{tabular}

Tabel 2. Kisi-Kisi Instrumen Gaya Kepemimpinan Situasional Kepala Sekolah

\begin{tabular}{|c|c|c|c|c|}
\hline Dimensi & Indikator & Positif (+) & Negati (-) & Jumlah \\
\hline \multirow{7}{*}{ Gaya instruktif } & 1. Mengarahkan tugas-tugas & 1 & 13 & 2 \\
\hline & 2. Memberikan penjelasan & 14 & 9 & 2 \\
\hline & 3. Memberikan acuan & 10 & & 1 \\
\hline & $\begin{array}{l}\text { 4. Memberikan petunjuk } \\
\text { pelaksanaan }\end{array}$ & 12 & 7 & 2 \\
\hline & 5. Mengendalikan & 8 & 4 & 2 \\
\hline & 6. Memberikan gambaran & & 5 & 1 \\
\hline & 7. Mengawasi & 11 & & 1 \\
\hline \multirow[t]{5}{*}{ Gaya konsultatif } & 8. Melatih & 6 & 2 & 2 \\
\hline & 9. Menberi contoh-contoh kerja & 3 & 15 & 2 \\
\hline & 10. Mengarahkan garis besar & 16 & & 1 \\
\hline & 11. Memantau & 29 & 23 & 2 \\
\hline & 12. Menjelaskan & 26 & & 1 \\
\hline \multirow{6}{*}{ Gaya partisipatif } & 13. Memberi dorongan & 33 & & 1 \\
\hline & 14. Mendengarkan & 22 & 17 & 2 \\
\hline & 15. Memperhatikan & 31 & & 1 \\
\hline & 16. Menghargai & 25 & & 1 \\
\hline & 17. Memberi dukungan & 20 & & 1 \\
\hline & 18. Menyusun keputusan & 35 & 27 & 2 \\
\hline \multirow[t]{2}{*}{ Gaya Delegatif } & 19. Melimpahkan wewenang & 19 & & 1 \\
\hline & 20. Mau bekerja & 30 & & 1 \\
\hline
\end{tabular}




\begin{tabular}{clccc}
\hline Dimensi & \multicolumn{1}{c}{ Indikator } & Positif (+) & Negati (-) & Jumlah \\
\hline & 21. Mampu bekerja & 24 & & 1 \\
& 22. Memberikan ganjaran & 18 & & 1 \\
23. Meningkatkan moral kerja & 28 & 32 & 1 \\
Fungsi Inovator & $\begin{array}{l}\text { 24. Pemrakarsa pembaharuan (agen } \\
\text { ofinnovation) dalam KMB }\end{array}$ & 21 & & 1 \\
& $\begin{array}{l}\text { 25. Pembaharuan dalam pembinaan } \\
\text { guru }\end{array}$ & 34 & & 1 \\
\hline
\end{tabular}

Tabel 3. Kisi-Kisi Instrumen Resiliensi Diri Guru

\begin{tabular}{|c|c|c|c|c|}
\hline Dimensi & Indikator & Positif(-) & Negati(+) & Jumlah \\
\hline \multirow[t]{2}{*}{ Regulasi Emosi } & 1. Tetap tenang menghadapi masalah. & 1,2 & 3 & 3 \\
\hline & 2. Fokus terhadap masalah yang ada & 4,5 & 6 & 3 \\
\hline \multirow[t]{2}{*}{ Kontrol Impuls } & 3. Mampu mengendalikan emosi negatif & 7,8 & & 2 \\
\hline & $\begin{array}{l}\text { 4. Mengontrol impuls yang membawa } \\
\text { kepada kemampuan berfikir jernih } \\
\text { dan akurat }\end{array}$ & 9 & 10 & \\
\hline \multirow[t]{2}{*}{ Empati } & 5. Memahami perilaku verbal orang lain & & 11 & 1 \\
\hline & $\begin{array}{l}\text { 6. Memahami perilaku nonverbal orang } \\
\text { lain }\end{array}$ & 12,13 & 14 & 3 \\
\hline \multirow[t]{2}{*}{ Optimis } & $\begin{array}{l}\text { 7. Yakin memiliki kemampuan untuk } \\
\text { menghadapi segala sesuatu }\end{array}$ & 15,16 & 17 & 3 \\
\hline & $\begin{array}{l}\text { 8. Percaya segala sesuatu menjadi lebih } \\
\text { baik }\end{array}$ & 18,19 & 35 & 3 \\
\hline \multirow[t]{2}{*}{ Analisis Kasual } & $\begin{array}{l}\text { 9. Mampu mengidentifikasi penyebab } \\
\text { masalah }\end{array}$ & 20 & 21 & 2 \\
\hline & $\begin{array}{l}\text { 10. Membuat solusi atas masalah yang } \\
\text { dihadapi }\end{array}$ & & 23 & 1 \\
\hline \multirow[t]{2}{*}{ Efikasi Diri } & $\begin{array}{l}\text { 11. Memiliki keyakinan untuk mengatasi } \\
\text { masalah }\end{array}$ & 22,24 & 26 & 3 \\
\hline & 12. Memiliki keyakinan untuk sukses & 25,27 & 29 & 3 \\
\hline \multirow[t]{2}{*}{$\begin{array}{l}\text { Pencapaian } \\
\text { (reaching out) }\end{array}$} & $\begin{array}{l}\text { 13. Mampu membedakan resiko yang } \\
\text { realistis dan tidak realitis }\end{array}$ & 28,30 & 32 & 3 \\
\hline & 14. Berani mengoptimalkan kemampuan & 31,33 & 34 & 3 \\
\hline
\end{tabular}

Metode analisis data yang digunakan adalah statistik inferensial. Uji prasyarat analisis regresi sebelum tahap pengujian hipotesis data adalah uji normalitas, uji linieritas, uji multikolinieritas dan uji heteroskedastisitas. Setelah uji prasyarat terpenuhi, digunakan regresi linier sederhana untuk menguji hipotesis pertama dan kedua, dan regresi linier berganda digunakan untuk menguji hipotesis ketiga, dan dilakukan pengujian hipotesis.

\section{Hasil dan Pembahasan}

Data yang diperoleh dari hasil penelitian ini adalah data hasil kuesioner kinerja guru, hasil kuesioner gaya kepemimpinan situasional kepala sekolah dan hasil kuesioner resiliensi diri guru yang dijadikan sampel dalam penelitian ini.

Data yang dipaparkan dalam penelitian ini adalah data gaya kepemimpinan situasional kepala sekolah dan resiliensi diri guru sebagai variabel bebas $(\mathrm{X})$ dan kinerja guru sebagai variabel terikat (y). Sampel data penelitian sebanyak 35 guru PNS. Sebelum melakukan pengujian hipotesis dapat melengkapi deskripsi data yang dilakukan dengan uji prasyarat meliputi uji normalitas, uji linieritas, uji multikolinieritas dan uji heterogenitas. Deskripsi data kinerja guru dapat dilihat pada Gambar 1 . 


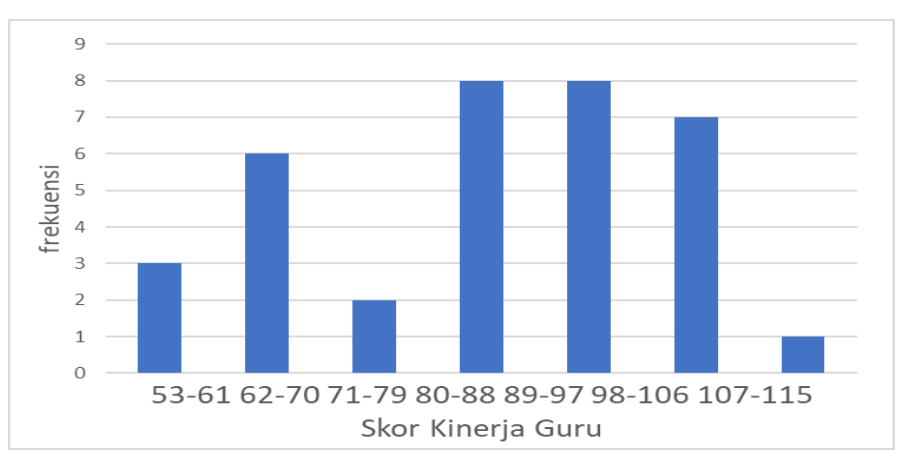

Gambar 1. Deskripsi Data Kinerja Guru

Data histogram pada gambar di atas, memaparkan deskripsi data kinerja guru adalah 84,29 termasuk rentangan sedang karena berdasarkan dari hasil analisis data rata-rata kinerja guru adalah 80-88 dan terdapat pada rentangan sedang dengan krteria pada konversi Skala 5 teoritik. Sedangkan deskripsi data gaya kepemimpinan situasional kepala sekolah dapat dilihat pada Gambar 2.

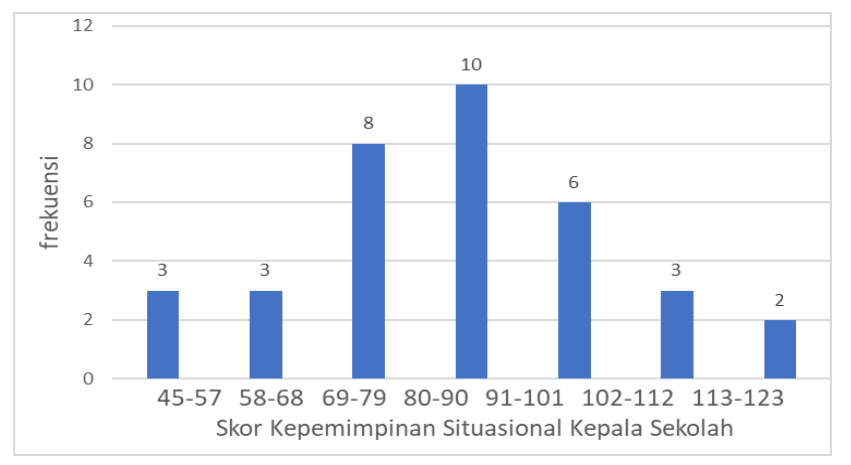

Gambar 2. Deskripsi Data Gaya Kepemimpinan Situasional Kepala Sekolah

Data histogram pada gambar 2, memaparkan deskripsi data gaya kepemimpinan situasional kepala sekolah adalah 83,26 termasuk rentangan sedang karena berdasarkan dari hasil analisis data rata-rata gaya kepemimpinan situasional kepala sekolah adalah 80-90 dan terdapat pada rentangan sedang dengan krteria pada konversi Skala 5 teoritik. Kemudian, Deskripsi data resiliensi diri guru dapat dilihat pada Gambar 3.

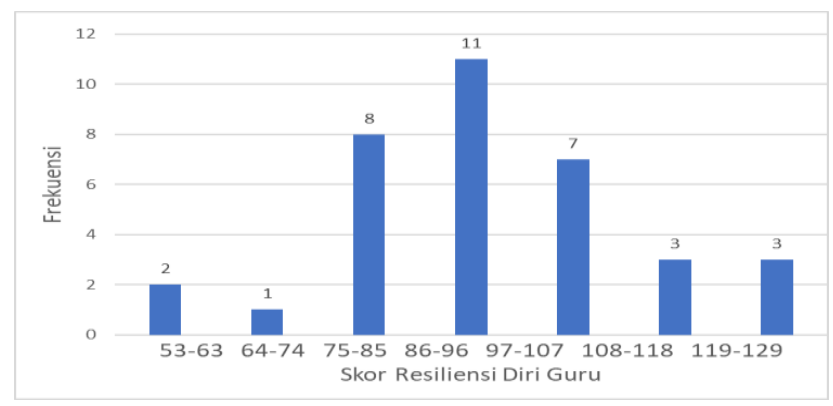

Gambar 3. Deskripsi Data Resiliensi Diri Guru

Data histogram pada gambar 3, memaparkan deskripsi resiliensi diri guru adalah 94 termasuk rentangan sedang karena berdasarkan dari hasil analisis data rata-rata resiliensi diri guru adalah 86 96 dan terdapat pada rentangan sedang dengan krteria pada konversi Skala 5 teoritik.

Sebelum dilakukan analisis uji hipotesis, terlebih dahulu dilakukan uji prasyarat yang meliputi uji normalitas, uji linieritas, uji multikolinearitas dan uji heterogenitas. Uji normalitas yang digunakan dalam penelitian ini adalah uji untuk melihat residual sebaran data yang dimiliki berasal dari sebaran normal atau tidak yaitu menggunakan Teknik Kolmogorov Smirnov dimana untuk menguji nilai 
residual tiap variable. Kriteria pengujian, jika nilai $|\mathrm{Ft}-\mathrm{Fs}| \mathrm{Max}>\mathrm{KS}$ tabel maka data berdistribusi normal. Sedangkan jika |Ft- Fs $\mid$ Max < KS tabel, maka sebaran data tidak berdistribusi normal, KS tabel dalam Penelitian ini diperoleh nilai 0,224. Berdasarkan hasil perhitungan dengan menggunakan rumus Kolmogorov Smirnov, diperoleh data hasil penelitian berdistribusi normal. Hasil uji normalitas nilai residual guru dapat dilihat pada Tabel 4.

Tabel 4. Hasil Uji Normalitas Nilai Residual Guru

\begin{tabular}{|c|c|c|c|}
\hline Variabel & $|\mathrm{Ft}-\mathrm{Fs}| \mathrm{Max}$ & Ks Tabel & Kesimpulan \\
\hline $\begin{array}{l}\text { Gaya Kepemimpinan Situasional Kepala Sekolah } \\
\text { Terhadap Kinerja Guru (X1 Y) }\end{array}$ & 0,120 & 0,224 & $\begin{array}{l}\text { Berdistribusi } \\
\text { Normal }\end{array}$ \\
\hline $\begin{array}{l}\text { Resiliensi Diri Guru Terhadap Kinerja Guru (X2 Y) } \\
\text { Gaya Kepemimpinan Situasional Kepala Sekolah }\end{array}$ & 0,094 & 0,22 & $\begin{array}{l}\text { Berdistribusi } \\
\text { Normal }\end{array}$ \\
\hline $\begin{array}{l}\text { dan Resiliensi Diri Guru Terhadap Kinerja Guru } \\
\text { (X1 X2 Y) }\end{array}$ & 0,152 & 0,224 & $\begin{array}{l}\text { Berdistribusi } \\
\quad \text { Normal }\end{array}$ \\
\hline
\end{tabular}

Dapat simpulkan bahwa data yang diujikan sepeti: gaya kepemimpinan situasional kepala sekolah terhadap kinerja guru, resiliensi diri guru terhadap kinerja guru, gaya kepemimpinan situasional kepala sekolah dan resiliensi diri guru terhadap kinerja guru berdistribusi normal dengan nilai |Ft-Fs| Max berturut-turut 0,120, 0,094 dan 0,152.

Selanjutnya pengujian dengan menggunakan uji linearitas untuk mengetahui hubungan gaya kepemimpinan situasional kepala sekolah dengan kinerja guru dan hubungan antara resiliensi diri guru dengan kinerja guru. Kriteria pengujian linearitas Deviation for Linierity yaitu, jika Deviation for Linierity lebih besar dari Taraf Signifikan maka dapat ditarik kesimpulan bahwa antara variabel X dan Y memiliki hubungan yang liniear. Pengujian linearitas dilakukan dengan bantuan aplikasi program SPSS Versi 16.0 dan dari hasil yang didapatkan harga Deviation From Linearity= 0,139 > 0,05 dapat disimpulkan bahwa data X1 terhadap Y atau data gaya kepemimpinan situasional kepala sekolah dengan kinerja guru bersifat linear. Uji linear data X2 terhadap Y atau data resiliensi diri guru dengan kinerja guru juga bersifat linear, dimana harga Deviation From Linearity =0,696 > 0,05. Deskripsi data resiliensi diri guru dapat dilihat pada Tabel 5.

Tabel 5. Hasil Uji Linieritas Data Guru

\begin{tabular}{lccc}
\hline \multicolumn{1}{c}{ Variabel } & $\begin{array}{c}\text { Deviation from } \\
\text { Linearity }\end{array}$ & $\begin{array}{c}\text { Taraf } \\
\text { Signifikan }\end{array}$ & Kesimpulan \\
\hline $\begin{array}{l}\text { Gaya Kepemimpinan } \\
\text { Situasional Kepala }\end{array}$ & 0,139 & 0,05 & Linier \\
$\begin{array}{l}\text { Sekolah } \\
\text { Terhadap Kinerja Guru }\end{array}$ & & & \\
$\begin{array}{l}\text { X1Y) } \\
\text { Resiliensi Diri Guru Terhadap } \\
\text { Kinerja Guru (X2Y) }\end{array}$ & 0,696 & 0,05 & Linier \\
\hline
\end{tabular}

Pengujian dengan menggunakan uji Multikolinieritas untuk mengetahui hubungan linear antar variabel independen dalam sebuah model regresi. Uji multikolinieritas menggunakan aplikasi program SPSS Versi 16.0 yaitu melihat nilai Variance Inflation Factor (VIF) dan Collinierity Tolerance. Metode regresi dianggap baik jika nilai Variance Inflation Factor $(V I F)$ dibawah $10(\leq 10)$ dan nilai Collinierity Tolerance diatas $0,1(\geq 0,1)$. Hasil analisis yang didapat dan dapat, VIF 1,377 dan TOL sebesar 0,726 maka disimpulkan bahwa tidak terjadi multikolinieritas dikarenakan Tol $>0,1$ dan VIF $<10$. Hasil uji multikolinieritas data guru dapat dilihat pada Tabel 6. 
Tabel 6. Hasil Uji Multikolinieritas Data Guru

\begin{tabular}{lccc}
\hline \multicolumn{1}{c}{ Variabel } & Tolerance & VIF & Ket \\
\hline Gaya & 0,726 & 1,377 & Tidak Terjadi \\
$\begin{array}{l}\text { Kepemimpinan } \\
\text { Situasional Kepala } \\
\text { Sekolah }\end{array}$ & & & Multikolinieritas \\
Resiliensi Diri Guru & 0,726 & 1,377 & Tidak Terjadi \\
& & & Multikolinieritas \\
\hline
\end{tabular}

Pengujian dengan menggunakan Uji heterokesdastisitas yang dapat digunakan adalah uji Glejser berbantuan aplikasi program SPSS Versi 16.0 dengan kriteria jika > 0,05 tidak terjadi heterokedastisidas begitu pula sebaliknya. Hasil uji heterokedastisidas data penelitian pada tabel 7, dapat dilihat nilai signifikansinya pada variabel konsep diri dan kebiasaan belajar terhadap kompetensi pengetahuan matematika secara berturut-turut adalah 0,126 dan 0,733>0,05. Jadi dapat disimpulkan bahwa tidak terjadi heteroskedastisitas pada model regresi dalam penelitian ini. Hasil uji heterokesdastisitas juga dapat dilihat dari output program SPSS dalam bentuk tabel sebagai berikut. Kemudian, untuk hasil uji heteroskesdastisitas data guru dapat dilihat pada Tabel 7.

Tabel 7. Hasil Uji Heteroskesdastisitas Data Guru

\begin{tabular}{lcc}
\hline \multicolumn{1}{c}{ Variabel } & Sig & Ket \\
\hline $\begin{array}{l}\text { Gaya Kepemimpinan Situasional } \\
\text { Kepala Sekolah }\end{array}$ & 0,126 & Tidak Terjadi \\
Resiliensi Diri Guru & & heteroskesdastisitas \\
& 0,733 & Tidak Terjadi \\
& & heteroskesdastisitas \\
\hline
\end{tabular}

Setelah dilakukan uji prasyarat analisis maka pengujian hipotesis. Hasil penelitian menunjukkan bahwa terdapat kontribusi yang signifikan gaya kepemimpinan situasional kepala sekolah terhadap kinerja guru SD Gugus I Kecamatan Blahbatuh tahun ajaran 2020/2021 dan kontribusinya sebesar 14,56\%, juga terdapat kontribusi yang signifikan resiliensi diri guru terhadap kinerja guru SD Gugus I Kecamatan Blahbatuh tahun ajaran 2020/2021 dan kontribusinya sebesar $61,03 \%$ serta terdapat kontribusi yang signifikan gaya kepemimpinan situasional kepala sekolah dan resiliensi diri guru terhadap kinerja guru SD Gugus I Kecamatan Blahbatuh tahun ajaran 2020/2021dan kontribusinya sebesar 75,59\%.

Dalam penelitian ini, hipotesisi yang diujikan adalah $\mathrm{H}_{0}$ yaitu, (1) tidak terdapat kontribusi yang signifikan antara gaya kepemimpinan situasional kepala sekolah terhadap kinerja guru Guru SD Gugus 1 Kecamatan Blahbatuh Tahun Ajaran 2020/2021, (2) tidak terdapat kontribusi yang signifikan antara resiliensi diri guru terhadap kinerja guru Guru SD Gugus 1 Kecamatan Blahbatuh Tahun Ajaran 2020/2021, dan (3) tidak terdapat kontribusi yang signifikan antara jika gaya kepemimpinan situasional kepala sekolah dan resiliensi diri guru Guru SD Gugus 1 Kecamatan Blahbatuh Tahun Ajaran 2020/2021.

Dari hasil pengujian hipotesis yang pertama yaitu kontribusi gaya kepemimpinan situasional kepala sekolah terhadap kinerja guru menggunakan teknik analisis regresi linear sederhana yang

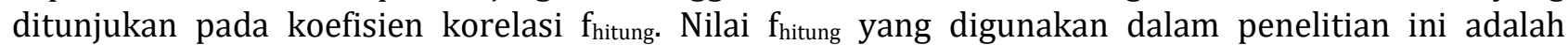
sebesar $=14,356$ dengan nilai $\mathrm{f}_{\text {tabel }}$ adalah sebesar $=4,14$ pada taraf signifikan $5 \%$. Karena nilai $\mathrm{f}_{\text {hitung }}>$ $\mathrm{f}_{\text {tabel, }}$ maka koefisien ini signifikan yang memiliki arti bahwa gaya kepemimpinan situasional kepala sekolah memiliki hubungan yang positif terhadap kinerja guru. Kekuatan hubungan variabel gaya kepemimpinan situasional kepala sekolah terhadap kinerja guru diperoleh melalui koefisien korelasi rxy $=0,5508$. Sumbangan efektif (SE) gaya kepemimpinan situasional kepala sekolah terhadap kinerja guru yang diperoleh adalah $11,24 \%$, jadi kinerja guru ditentukan oleh gaya kepemimpinan situasional kepala sekolah. Sedangkan sebanyak 88,76 disebabkan oleh faktor lain. Dengan demikian, maka $\mathrm{H}_{0}$ ditolak dan Ha diterima, dapat disimpulkan bahwa terdapat kontribusi yang signifikan gaya kepemimpinan situasional kepala sekolah terhadap kinerja guru Guru SD Gugus 1 Kecamatan 
Blahbatuh Tahun Ajaran 2020/2021. Jadi semakin tinggi gaya kepemimpinan situasional kepala sekolah maka kinerja guru semakin meningkat.

Dari hasil pengujian hipotesis yang kedua yaitu kontribusi resiliensi diri guru terhadap kinerja guru menggunakan teknik analisis regresi linear sederhana yang ditunjukan pada koefisien korelasi $\mathrm{f}_{\text {hitung. }}$. Nilai $\mathrm{f}_{\text {hitung }}$ yang digunakan dalam penelitian ini adalah sebesar $=48,036$ dengan nilai $\mathrm{f}_{\text {tabel }}$ adalah sebesar $=4,14$ pada taraf signifikan $5 \%$. Karena nilai $f_{\text {hitung }}>f_{\text {tabel, }}$, maka koefisien ini signifikan yang memiliki arti bahwa resiliensi diri guru memiliki hubungan yang positif terhadap kinerja guru. Kekuatan hubungan variabel resiliensi diri guru terhadap kinerja guru diperoleh melalui koefisien korelasi rxy $=0,7699$. Sumbangan efektif (SE) resiliensi diri guru yang diperoleh adalah $51,04 \%$, jadi kinerja guru ditentukan oleh resiliensi diri guru, Sedangkan sebanyak 48,96 disebabkan oleh faktor lain. Dengan demikian, maka $\mathrm{H}_{0}$ ditolak dan $\mathrm{Ha}$ diterima, dapat disimpulkan bahwa terdapat kontribusi yang signifikan resiliensi diri guru terhadap kinerja guru Guru SD Gugus 1 Kecamatan Blahbatuh Tahun Ajaran 2020/2021. Jadi semakin baik resiliensi diri guru maka kinerja guru semakin meningkat.

Dari hasil pengujian hipotesis yang ketiga yaitu kontribusi gaya kepemimpinan situasional kepala sekolah dan resiliensi diri guru terhadap kinerja guru menggunakan teknik regresi linear ganda yang ditunjukan pada koefisien korelasi $f_{\text {hitung. }}$. Nilai $f_{\text {hitung }}$ yang digunakan dalam penelitian ini adalah sebesar $=26,437$ dengan nilai $\mathrm{f}_{\text {tabel }}$ adalah sebesar $=3,29$ pada taraf signifikan $5 \%$. Karena nilai $\mathrm{f}_{\text {hitung }}>$ $\mathrm{f}_{\text {tabel, }}$ maka koefisien ini signifikan yang memiliki arti bahwa gaya kepemimpinan situasional kepala sekolah dan resiliensi diri guru memiliki hubungan yang positif terhadap terhadap kinerja guru. Kekuatan hubungan variabel gaya kepemimpinan situasional kepala sekolah dan resiliensi diri guru terhadap kinerja guru diperoleh melalui koefisien korelasi $\operatorname{Ry}_{(1,2)}=0,789$. Sumbangan efektif (SE) resiliensi diri guru yang diperoleh adalah 62,28\%, jadi kinerja guru ditentukan oleh gaya kepemimpinan situasional kepala sekolah dan resiliensi diri guru, Sedangkan sebanyak 37,72 disebabkan oleh faktor lain. Dengan demikian, maka $\mathrm{H}_{0}$ ditolak dan Ha diterima, dapat disimpulkan bahwa terdapat kontribusi yang signifikan gaya kepemimpinan situasional kepala sekolah dan resiliensi diri guru terhadap kinerja guru Guru SD Gugus 1 Kecamatan Blahbatuh Tahun Ajaran 2020/2021. Semakin gaya kepemimpinan situasional kepala sekolah dan resiliensi diri guru maka kinerja guru semakin meningkat.

Hasil uji hipotesis dapat diinterpetasikan, jika gaya kepemimpinan situasional kepala sekolah dan resiliensi diri guru maka akan mempengaruhi kinerja guru menjadi baik dalam suatu sekolah. Maka secara bersama-sama terjadi hubungan yang signifikan antara gaya kepemimpinan situasional kepala sekolah dan resiliensi diri guru terhadap kinerja guru. Penelitian ini sejalan dengan penelitian yang dilakukan oleh (Ardiana, 2017; Pramesti \& Muhyadi, 2018; Sukiyanto \& Maulidah, 2020) bertujuan untuk mengetahui pengaruh motivasi kerja terhadap kinerja guru akuntansi. Penelitian ini menggunakan pendekatan studi korelasional. Variabel penelitian ini terdiri atas satu variabel bebas yaitu: motivasi kerja $(\mathrm{X})$ dan satu variabel terikat yaitu: kinerja guru akuntansi (Y). Pengumpulan data dilakukan dengan menggunakan alat kuesioner berstruktur tertutup. Hasil pengumpulan data selanjutnya dianalisis menggunakan teknik analisis regresi sederhana dan regresi berganda dengan bantuan SPSS Versi 20. Hasil penelitian menunjukkan bahwa motivasi kerja berpengaruh secara positif terhadap kinerja guru akuntansi. Kemudian, penelitian yang dilakukan oleh (Dwiyani \& Sarino, 2018; Erawan \& Sukartha, 2018; Yayuk \& Sugiyono, 2019) bertujuan untuk menganalisis pengaruh gaya kepemimpinan situasional kepala sekolah dan motivasi kerja guru terhadap kinerja guru. Metode penelitian menggunakan metode survey. Teknik pengumpulan data menggunakan angket model rating scale dengan skor yang terentang antara 1 sampai dengan 5. Teknik analisis data menggunakan regresi. Hasil penelitian menunjukkan gaya kepemimpinan situasional dan motivasi kerja berpengaruh positif dan signifikan terhadap kinerja guru, baik secara parsial maupun secara simultan. Dengan demikian kinerja guru dapat ditingkatkan melalui peningkatan gaya kepemimpinan situiasional kepala sekolah dan motivasi kerja guru.

Kepemimpinan dikatakan sebagai proses yang dilakukan pemimpin agar bisa dalam melakukan sesuatu dan kepemimpinan tidak hanya untuk menempati posisi otoritatif. Gaya kepemimpinan kepala sekolah merupakan salah satu yang dapat memajukan tujuan tertentu yang direncanakan. Kepemimpinan kepala sekolah yang baik dapat membuat anggotanya percaya, setia dan termotivasi untuk melaksanakan tugas organisasi secara maksimal (Sukiyanto \& Maulidah, 2020; 
Wahyudin, 2018; Yayuk \& Sugiyono, 2019). Di sekolah, gaya kepemimpinan situasional kepala sekolah sangat penting untuk mengatasi berbagai permasalahan di sekolah dan pendidikan guru.

Gaya kepemimpinan situasional merupakan model gaya kepemimpinan yang berfokus pada pengikut, pengikut yang relevan adalah karyawan di perusahaan (Saragih \& Simarmata, 2018; Umi et al., 2019; Yayuk \& Sugiyono, 2019). Kepemimpinan yang sukses dicapai dengan memilih cara memimpin yang benar, dan bergantung pada kesiapan dan kematangan pengikutnya. Gaya kepemimpinan situasional kepala sekolah yang efektif dapat diartikan sebagai pemimpin bisa meningkatkan kinerja semua anggotanya dalam mencapai tujuan tertentu. Menerapkan gaya kepemimpinan situasional dengan melihat kematangan dan kesiapan karyawan dan pendekatan gaya kepemimpinan situasional berfokus pada karyawan atau pengikut dalam organisasi.

Fungsi kepala sekolah sebagai pemimpin sekolah, yaitu: (1) meningkatkan mutu sekolah, seperti menyediakan fasilitas yang memadai bagi seluruh komponen sekolah; (2) Sebagai pedoman untuk meningkatkan kualitas guru dan seluruh staf sekolah melalui pertemuan, dan observasi kelas, (Aisyah \& Takdir, 2017; Dwiyani \& Sarino, 2018; Suparno, 2013). Fungsi tersebut dijadikan landasan untuk melaksanakan tugas kepala sekolah sebagai pemimpin sekolah misalnya mengajar guru, membimbing staf, membimbing siswa, melatih staf, mengikuti perkembangan iptek, dan sebagainya. Namun sebagai kepala sekolah yang baik harus menyadari pentingnya kinerja guru.

Kepala sekolah berperan penting dalam pengelolaan lembaga sekolah, salah satunya meliputi aspek keuangan. Keuangan dan keuangan merupakan bagian integral dari manajemen pendidikan, dengan kata lain mengingat setiap kegiatan sekolah membutuhkan uang, maka diperlukan pengelolaan komponen keuangan dan keuangan ini secara lebih efektif, efektif, transparan dan bertanggung jawab agar dana yang ada dapat mendukung sekolah untuk mencapai tujuan pendidikan yang ada (Erawan \& Sukartha, 2018; Sukiyanto \& Maulidah, 2020; Winarsih, 2018). Keberhasilan penyelenggaraan pendidikan sebagai tolak ukur kinerja guru di sekolah bergantung pada kemampuan kepemimpinan kepala sekolah dalam mengelola staf sekolah. Faktor kepemimpinan utama dianggap memiliki peran penting, karena sebagai pemimpin sekolah maka gaya dan kebijakan kepemimpinan akan sangat mempengaruhi kinerja guru. Pendidikan di SD merupakan pondasi untuk mencapai tingkat pendidikan selanjutnya seperti SMP, SMA dan SMK maupun perguruan tinggi. Belum lagi guru terbebani oleh kompetensi yang distandarkan oleh pihak sekolah masing-masing. Kemampuan guru untuk bertahan dari tuntutan tersebut dapat dikatakan sebagai resiliensi.

Resiliensi adalah kekuatan yang dimiliki seseorang untuk menghadapi, mengatasi, dan untuk menjadi kuat terhadap kesulitan hidup yang tak dapat di hindari (Akbar \& Pratasiwi, 2017; Hafiva et al., 2020; Sutrisno, 2017). Selain itu resiliensi dapat diartikan sebagai ilmu psikologi positif yang menginstruksikan individu untuk lebih realistis dalam menghadapi masalah dalam hidup. Jika resiliensi guru terganggu makan akan berpengaruh juga dengan kinerja seorang guru.

Penelitian ini diperkuat dengan beberapa penelitian sebelumnya yang relevan dengan penelitian ini, seperti: (1) penelitian yang dilakukan oleh (Sukiyanto \& Maulidah, 2020), yang memperoleh hasil penelitian bahwa gaya kepemimpinan kepala sekolah dan budaya organisasi berpengaruh terhadap motivasi guru dan karyawan; (2) penelitian yang dilakukan oleh (Ramadoni et al., 2016), yang memperoleh hasil penelitian bahwa kepemimpinan kepala sekolah terbukti dapat meningkatkan kinerja guru; (3) penelitian yang dilakukan oleh (Umi et al., 2019), yang memperoleh hasil penelitian bahwa kepemimpinan kepala taman kanak-kanak berkorelasi terhadap kinerja kompetensi pedagogik dan kompetensi profesional guru. Implikasi dari pelaksanaan penelitian studi korelasi (expost facto) ini adalah meningkatkan mutu sekolah, dan dijadikan sebagai pedoman untuk meningkatkan kualitas guru dan seluruh staf sekolah.

\section{Simpulan}

Gaya kepemimpinan situasional dan resiliensi diri guru memiliki kontribusi terhadap kinerja guru SD gugus 1 Kecamatan Blahbatuh tahun ajaran 2020/2021. Implikasi dari pelaksanaan penelitian ini adalah meningkatkan mutu sekolah, dan dijadikan sebagai pedoman untuk meningkatkan kualitas guru dan seluruh staf sekolah. 


\section{Daftar Pustaka}

Ahmadiansah, R. (2016). Pengaruh Motivasi Kerja Dan Kepuasan Kerja Terhadap Kinerja Guru SMK Muhammadiyah Salatiga. Interdisciplinary Journal of Communication, 1(2), 1-27. https://doi.org/10.18326/inject.v1i2.223-236

Aisyah, S., \& Takdir, S. (2017). Implementasi Gaya Kepemimpinan Situasional Kepala Sekolah Di SMP Negeri 1 Wamena Kabupaten Jayawijaya. Magister Manajemen Fakultas Ekonomika Dan Bisnis, 2(2), 1-16. https://doi.org/10.34125/kp.v2i2.116

Akbar, Z., \& Pratasiwi, R. (2017). Resiliensi Diri Dan Stres Kerja Pada Guru Sekolah Dasar. JPPP: Jurnal Penelitian Dan Pengukuran Psikologi, 6(2), 106-112. https://doi.org/10.21009/jppp.062.08

Ardiana, T. E. (2017). Pengaruh Motivasi Kerja Guru Terhadap Kinerja Guru Akuntansi Smk Di Kota Madiun. Jurnal Akuntansi Dan Pajak, 17(02), 14-23. https://doi.org/10.29040/jap.v17i02.11

Dudung, A. (2018). Kompetensi Profesional Guru (Suatu Studi Meta-Analysis Desertasi Pascasarjana UNJ). JKKP Uurnal Kesejahteraan Keluarga Dan Pendidikan), 5(1), 9-19. https://doi.org/10.21009/jkkp.051.02

Dwiyani, D., \& Sarino, A. (2018). Gaya Kepemimpinan Situasional Kepala Sekolah Dan Motivasi Kerja Guru Sebagai Determinan Kinerja Guru. Jurnal Manajemen Dan Sistem Informasi, 17(1), 83-94. https://doi.org/10.17509/manajerial.v17i1.9763

Erawan, N. M. A. N. P., \& Sukartha, I. M. (2018). Pengaruh Kompetensi, Pengalaman Kerja, Gaya Kepemimpinan dan Lingkungan Kerja Pada Kualitas Audit. E-Jurnal Akuntansi, 24(3), 23602388. https://doi.org/10.24843/eja.2018.v24.i03.p27

Hafid, M. (2017). Pengaruh Motivasi dan Kompetensi Guru Terhadap Kinerja Guru Sekolah dan Madrasah di Lingkungan Pondok Pesantren Salafiyah Syafi'iyah Sukorejo. Jurnal Pendidikan Islam Indonesia, 1(2), 293-314. https://doi.org/10.35316/jpii.v1i2.55

Hafiva, W., Yusri, F., \& Aprison, W. (2020). Efektivitas Pendekatan Ego Untuk Meningkatkan Resiliensi Diri Siswa di SMAN 2 Padang Panjang. Islamic Counseling: Jurnal Bimbingan Konseling Islam, 4(2), 223-236. https://doi.org/10.29240/jbk.v4i2.1474

Kartowagiran, B. (2015). Kinerja Guru Profesional (Guru Pasca Sertifikasi). Jurnal Cakrawala Pendidikan, 30(3). https://doi.org/10.21831/cp.v3i3.4208

Luddin, A. B. M. (2014). Kinerja Kepala Sekolah Dalam Kegiatan Bimbingan Dan Konseling. Jurnal Ilmu Pendidikan, 19(2). https://doi.org/10.17977/jip.v19i2.4216

Nugraha, D. (2017). Kontribusi Kompetensi Pedagogik Dan Motivasi Berprestasi Terhadap Kinerja Pengasuh Paud Di Kabupaten Ciamis. Jurnal Paud Agapedia, 1(2), 160-169. https://doi.org/10.17509/jpa.v1i2.9356

Pramesti, D., \& Muhyadi. (2018). Faktor-Faktor Yang Mempengaruhi Kinerja Guru SMA. Harmoni Sosial: Jurnal Pendidikan IPS, 5(1), 43-56. https://doi.org/10.21831/hsjpi.v5i1.11854

Priyono, B. H., Qomariah, N., \& Winahyu, P. (2018). Pengaruh Gaya Kepemimpinan, Motivasi Guru Dan Lingkungan Kerja Fisik Terhadap Kinerja Guru SMAN 1 Tanggul Jember. Jurnal Manajemen Dan Bisnis Indonesia, 4(2), 144-160. https://doi.org/10.32528/jmbi.v4i2.1758

Purwanti, K., AR, M., \& Yusrizal, Y. (2014). Kepemimpinan Kepala Sekolah Dalam Meningkatkan Kompetensi Guru Pada Smp Negeri 2 Simeulue Timur. Jurnal Ilmiah Didaktika, 14(2), 390-400. https://doi.org/10.22373/jid.v14i2.510

Ramadoni, W., Kusmintardjo, \& Arifin, I. (2016). Kepemimpinan Kepala Sekolah Dalam Upaya Peningkatan Kinerja Guru (Studi Multi Kasus Di Paud Islam Sabilillah Dan SDN Tanjungsari 1 Kabupaten Sidoarjo). Jurnal Pendidikan: Teori, Penelitian, DanPengembangan, 1(8), 1500-1504. https://doi.org/10.17977/jp.v1i8.6620

Salmawati, Rahayu, T., \& Lestari, W. (2017). Kontribusi Kompetensi Pedagogik, Kompetensi Profesional Dan Motivasi Kerja Terhadap Kinerja Guru Penjasorkes Smp Di Kebupaten Pati. 
Journal of Physical Education and Sports, 6(2), 198-204.

Saragih, R. S., \& Simarmata, H. M. P. (2018). Kepemimpinan, Kepuasan Kerja dan Motivasi terhadap Kinerja Pegawai. Jurnal Ilmiah Manajemen Dan Bisnis, 19(2), 124-133. https://doi.org/https://doi.org/10.30596/jimb.v19i2.2146

Sukiyanto, \& Maulidah, T. (2020). Pengaruh Gaya Kepemimpinan Kepala Sekolah dan Budaya Organisasi terhadap Motivasi Guru dan Karyawan. Jurnal Pendidikan Edutama, 7(1), 127. https://doi.org/10.30734/jpe.v7i1.874

Suparno, A. (2013). Kontribusi Pelatihan Guru, Iklim Organisasi Dan Persepsi Guru Tentang Keterampilan Manajerial Kepala Sekolah Terhadap Keterampilan Guru Dalam Pembelajaran Smkn Kota Semarang. Jurnal Varidika, 25(1), 53-65. https://doi.org/10.23917/varidika.v25i1.719

Susanti, Y. (2016). Pengaruh Kompetensi dan Komitmen Profesionalitas Terhadap Kinerja Guru (Penelitian di SMP Negeri Komisariat 01 Ciamis). Jurnal Edukasi (Ekonomi, Pendidikan Dan Akuntansi), 4(2). https://doi.org/10.25157/je.v4i2.999

Sutrisno, B. (2017). Meningkatkan Resiliensi Peserta Didik Melalui Metode Problem Based Learning. Jurnal Pendidikan Ilmu Sosial, 25(2), 144-153. https://doi.org/10.17509/jpis.v25i2.6189

Suyitno, T. (2018). Pengaruh Hasil Diklat, Kompetensi Pedagogik, dan Kompetensi Profesional Terhadap Kinerja Guru. Andragogi: Jurnal Diklat Teknis Pendidikan Dan Keagamaan, 6(1), 122142. https://doi.org/10.36052/andragogi.v6i1.51

Umi, R., Nopriansyah, U., \& Purnama, S. (2019). Korelasi Kepemimpinan Kepala Taman Kanak-Kanak Terhadap Kinerja Kompetensi Pedagogik dan Kompetensi Profesional Guru. Al-Athfaal: Jurnal Ilmiah Pendidikan Anak Usia Dini, 2(1). https://doi.org/10.24042/ajipaud.v2i1.4552

Wahyudin, W. (2018). Optimalisasi Peran Kepala Sekolah dalam Implementasi Kurikulum 2013. Jurnal Kependidikan, 6(2), 249-265. https://doi.org/10.24090/jk.v6i2.1932

Winarsih, S. (2018). Gaya Kepemimpinan Kepala Sekolah dalam Meningkatkan Kinerja Guru. International Conference of Moslem Society, 2, 95-106. https://doi.org/10.24090/icms.2018.1864

Yayuk, S., \& Sugiyono, S. (2019). Pengaruh kepemimpinan kepala sekolah dan biaya pendidikan terhadap kualitas proses belajar mengajar dan dampaknya dengan kompetensi lulusan SMK di kabupaten Gunungkidul. Jurnal Akuntabilitas Manajemen Pendidikan, 7(1), 84-96. https://doi.org/10.21831/amp.v7i1.23758 